\title{
Lymphocytes with Immunoglobulin E Fc Receptors in Patients with Atopic Disorders
}

\author{
H. L. SPiegelberg, R. D. O'Connor, R. A. Simon, and D. A. MAthison, Departments \\ of Immunopathology and Clinical Research, Scripps Clinic and Research \\ Foundation, La Jolla, California 92037; Department of Pediatrics, University of \\ California at San Diego, La Jolla, California 9209.3
}

\begin{abstract}
A B S T R A C T Lymphocytes from normal nonallergic donors and patients with atopic disorders were analyzed for subpopulations bearing $\mathrm{Fc}_{\mathrm{c}}$ receptors for immunoglobulin $(\operatorname{Ig}) \mathrm{E}\left(\mathrm{Fc}_{\epsilon}\right)$ and $\operatorname{IgG}\left(\mathrm{Fc}_{\gamma}\right)$, surface $\operatorname{IgM}(\mathrm{s} \operatorname{IgM})$ and $\operatorname{IgD}(\mathrm{s} \operatorname{IgD})$, and for $\mathrm{T}$ cells forming spontaneous rosettes with sheep erythrocytes $(\mathrm{E})$. The patients were divided into three groups according to serum IgE concentrations and systemic corticosteroid treatment. Group I consisted of 12 atopic patients with either normal or moderately increased IgE levels up to 4,000 $\mathrm{U} / \mathrm{ml}$. Four patients of group II and three of group III had 10,500-31,000 U/ml and severe atopic dermatitis. Patients of group III, but not I and II, were receiving corticosteroids systemically. The percentage (mean $\pm \mathrm{SD}$ ) and total number of $\mathrm{Fc}_{\epsilon}{ }^{+}$lymphocytes were $1.2 \pm 0.5 \%, 41 \pm 24 / \mathrm{mm}^{3}$ in 12 normals; $1.6 \pm 0.9 \%$, $59 \pm 43 / \mathrm{mm}^{3}$ in patients of group I: $7.0 \pm 2.0 \%, 187$ $\pm 67 / \mathrm{mm}^{3}$ in group II; and $0.3 \pm 0.1 \%, 13 \pm 5 / \mathrm{mm}^{3}$ in patients of group III. The increase in group II and decrease in group III of $\mathrm{Fc}_{\epsilon}^{+}$cells were statistically significantly different from the normal persons and patients of group I. In contrast, the patients did not differ significantly from the donors in $\operatorname{sIgM}^{+}, \operatorname{sIgD}{ }^{+}$, $\mathrm{Fc}_{\gamma}{ }^{+}$, and $\mathrm{E}^{+}$cell populations. As shown by depletion of $\mathrm{sIg}^{+}$cells in four patients with atopic disorders, the great majority of the $\mathrm{Fc}_{\epsilon}{ }^{+}$lymphocytes were $\mathrm{B}$ cells. However, two patients with elevated $\mathrm{Fc}_{\epsilon}^{+}$cell numbers
\end{abstract}

Portions of this work were presented at the 24th Annual Meeting of the Western Association of Physicians, Carmel, Calif., February 1979; the Annual Meeting of the American Academy of Allergy, New Orleans, La., March 1979; and Federation of American Societies for Experimental Biology, Dallas, Tex., April 1979. This is publication No. 1745 from Scripps Clinic and Research Foundation.

Dr. Simon is a recipient of a fellowship award from the Allergy Foundation of America.

Address reprint requests to Dr. Spiegelberg, Scripps Clinic and Research Foundation.

Received for publication 26 March 1979 and in revised form 7 April 1979. had small numbers of mixed $E$ - and $\mathrm{Fc}_{\mathrm{c}^{-} \text {-rosetting }}$ cells, presumably $\mathrm{T}$ cells. Two patients of group II were examined during an acute herpes simplex infection. Both showed an $\cong 80 \%$ decrease of $\mathrm{Fc}_{\epsilon}{ }^{+}$cells at that time. No apparent correlation between numbers of $\mathrm{Fc}_{\epsilon}{ }^{+}$cells and $\operatorname{IgE}$ level existed in patients of group I. Injection of an IgE myeloma protein into two monkeys did not significantly change their percentages of $\mathrm{Fc}_{\epsilon}{ }^{+}$ lymphocytes.

The data indicate that $\mathrm{Fc}_{\epsilon}{ }^{+}$lymphocytes are increased in patients with markedly elevated serum IgE and severe atopic disease, suggesting that these cells may be involved in the regulation and(or) synthesis of IgE antibody formation.

\section{INTRODUCTION}

It is well known that immunoglobulin (Ig)E antibodies bind to high affinity $F_{c}$ receptors $\left(\mathrm{Fc}_{\epsilon}\right)^{1}$ on basophils and mast cells and, after reacting with antigen, cause these cells to release vasoactive substances (1). Recently, we described a subpopulation of lymphocytes that also has $\mathrm{Fc}_{\epsilon}$ receptors $(2-6)$. The majority of normal $(3,6)$, cultured (4), and chronic lymphatic leukemic (5) lymphocytes with $\mathrm{Fc}_{\epsilon}$ receptors had cell surface bound immunoglobulin ( $\mathrm{sIg}$ ) indicating that the cells were $\mathrm{B}$ lymphocytes. $\mathrm{Fc}_{\epsilon}$ receptors on lymphocytes differ most likely in structures from those on basophils and mast cells, since their affinity for monomeric IgE is low and because an antilymphocyte $\mathrm{Fc}_{\epsilon}$ receptor antiserum failed to release histamine from basophils (7). The number of $\mathrm{Fc}_{\epsilon}{ }^{+}$lymphocytes in the peripheral blood of normals is small. In our first report we found an average of $4 \%$ (3); however, in

\footnotetext{
${ }^{1}$ Abbreviations used in this paper: E, sheep erythrocyte; $\mathrm{E}_{0}$ and $\mathrm{E}_{0}{ }^{\prime}$, native and fixed ox erythrocyte; $\mathrm{Fc}_{\epsilon}$ and $\mathrm{Fc}_{\gamma}, \mathrm{Fc}_{\mathrm{c}}$ receptors for IgE and IgG; sIg, cell surface bound immunoglobulin; TH, Tris-buffered Hanks' balanced salt solution containing $2.5 \%$ heat-inactivated fetal calf serum.
} 
TABLE I

Clinical Data of Patients with Atopic Diseases

\begin{tabular}{|c|c|c|c|c|c|c|c|c|c|}
\hline \multirow[b]{2}{*}{ Patient } & \multirow[b]{2}{*}{$\begin{array}{l}\text { Age/ } \\
\text { Sex }\end{array}$} & \multirow[b]{2}{*}{ Diagnosis } & \multirow[b]{2}{*}{$\operatorname{IgE}$} & \multirow[b]{2}{*}{$\mathrm{Fr}_{e}^{+}$} & \multirow[b]{2}{*}{$\mathrm{Fc}_{e^{+}}^{+}$} & \multicolumn{4}{|c|}{ Treatment } \\
\hline & & & & & & $\begin{array}{c}\text { Systemic } \\
\text { steroid }\end{array}$ & $\begin{array}{l}\text { Local } \\
\text { steroid }\end{array}$ & $\begin{array}{c}\text { Anti- } \\
\text { histamine }\end{array}$ & Theophylline \\
\hline & & & $\mu g / m l$ & $\%$ & $m m^{3}$ & & & & \\
\hline \multicolumn{10}{|c|}{ Mild to moderate atopics } \\
\hline B. All & $47 \mathrm{~F}$ & AR, A, FA & 3.87 & 1.0 & 51.8 & - & + & + & - \\
\hline D. All & $27 \mathrm{~F}$ & AR & 4.60 & 1.8 & 37.5 & - & - & + & - \\
\hline Bar & $23 \mathrm{~F}$ & $\mathrm{AR}, \mathrm{A}$ & 1.09 & 2.0 & 63.4 & - & - & + & - \\
\hline $\mathrm{DeH}$ & $33 \mathbf{M}$ & $\mathrm{AD}, \mathrm{AR}, \mathrm{A}$ & 9.68 & 1.4 & 25.2 & - & - & - & + \\
\hline Fit & $32 \mathrm{~F}$ & AR & 0.02 & 3.0 & 106.0 & - & + & + & - \\
\hline Mat & $39 \mathrm{M}$ & AR & 0.09 & 1.1 & 62.0 & - & - & - & - \\
\hline Neh & $36 \mathbf{F}$ & AR, A & 1.40 & 3.3 & 171.6 & - & - & + & + \\
\hline Rey & $26 \mathrm{~F}$ & AR & 0.03 & 0.4 & 14.6 & - & - & - & - \\
\hline Sch & $40 \mathrm{~F}$ & $\mathrm{AD}, \mathrm{AR}, \mathrm{A}$ & 4.72 & 1.2 & 44.5 & - & - & + & + \\
\hline Sim & $27 \mathrm{~F}$ & AR, A & 0.44 & 1.0 & 41.9 & - & + & - & - \\
\hline Sno & $30 \mathrm{~F}$ & AR & 0.12 & 1.0 & 31.5 & - & - & - & - \\
\hline Wil & $28 \mathrm{~F}$ & AR, A & 1.40 & 1.4 & 51.9 & - & - & - & - \\
\hline \multicolumn{10}{|c|}{$\begin{array}{l}\text { Severe atopics without systemic } \\
\text { corticosteroid treatment }\end{array}$} \\
\hline Fer & $28 \mathrm{~F}$ & AD, AR, A & 75.02 & & & - & + & + & - \\
\hline Gre & $21 \mathrm{~F}$ & $\mathrm{AD}, \mathrm{AR}, \mathrm{A}$ & 47.19 & & & - & + & + & - \\
\hline Kan & $27 \mathrm{M}$ & $\mathrm{AD}, \mathrm{AR}, \mathrm{A}$ & 41.14 & & & - & + & + & + \\
\hline Pra & $32 \mathrm{~F}$ & $\mathrm{AD}, \mathbf{A R}, \mathbf{A}$ & 29.04 & & & - & + & + & + \\
\hline \multicolumn{10}{|c|}{$\begin{array}{l}\text { Severe atopics with systemic } \\
\text { corticosteroid treatment }\end{array}$} \\
\hline Bur & $40 \mathrm{M}$ & AD & 35.09 & & & + & + & + & - \\
\hline $\mathrm{Nic}$ & $63 \mathrm{~F}$ & $\mathrm{AD}, \mathrm{AR}, \mathrm{A}$ & 25.41 & & & + & + & + & + \\
\hline Rus & $19 \mathrm{~F}$ & $\mathrm{AD}, \mathrm{AR}, \mathrm{A}$ & 35.09 & & & + & + & + & + \\
\hline
\end{tabular}

Abbreviations used in this table: $\mathrm{AD}$, atopic dermatitis; $\mathrm{AR}$, allergic rhinitis; $\mathrm{A}$, asthma; $\mathrm{FA}$, food anaphylaxis.

subsequent studies only $1-2 \% \mathrm{Fc}_{\epsilon}{ }^{+}$lymphocytes could be demonstrated $(5,6)$.

Because patients with atopic disorders usually have elevated serum IgE concentrations, we investigated if they differ from normals in $\mathrm{Fc}_{\epsilon}{ }^{+}$lymphocytes. We also examined their lymphocytes for subpopulations having Fc receptors for IgG as well as B and T cells. Lymphocytes of four atopic patients were analyzed for the presence of $\mathrm{Fc}_{\epsilon}{ }^{+} \mathrm{T}$ cells by sIg depletion and mixed rosette experiments. Because $\mathrm{Fc}_{\epsilon}{ }^{+}$cells were increased in patients with very high IgE concentrations, two monkeys were injected with an IgE myeloma protein to determine if high IgE plasma levels influence the numbers of $\mathrm{Fc}_{\boldsymbol{\epsilon}}{ }^{+}$lymphocytes.

\section{METHODS}

Subjects. 12 healthy laboratory workers who had no history of atopic ${ }^{2}$ disorder and who had taken no medication for $72 \mathrm{~h}$ before testing, volunteered to serve as the normal controls.

2 "Atopic" is herein used meaning "associated with but not necessarily caused by reaginic (IgE) antibodies" as defined in Allergy Principles and Practice. 1978. E. Middleton, C. E. Reed, E. F. Ellis, editors. The C. V. Mosby Co., St. Louis.
The clinical data of the atopic patients are summarized in Table I. 12 patients with mild to moderate disease (group I) were randomly selected from the practice of one of the authors at the Cecil and Ida M. Green Hospital of Scripps Clinic. Most of these patients were studied at a time when their atopic disease was in spontaneous remission or controlled with medications taken with $72 \mathrm{~h}$ of blood sampling. The clinical diagnoses of allergic rhinitis and(or) asthma in these patients was confirmed by significant titers of skin sensitizing antibodies (IgE) to historically relevant allergens. The four patients of group II and three of group III with severe atopic dermatitis were selected from patients at the University Hospital, University of California at San Diego, San Diego, Calif., by Dr. O'Connor. The patients in these two groups had serum IgE levels $>10,000 \mathrm{U} / \mathrm{ml}$ and atopic dermatitis involving at least $75 \%$ of total body surface. Patients in groups II and III were using local corticosteroid at the time of study. In addition, group III patients were receiving systemic corticosteroids, and had been for at least $3 \mathrm{yr}$. Patients Nic and Rus (group III) were on alternative day prednisone, 15 and $10 \mathrm{mg}$ respectively, and were studied $48 \mathrm{~h}$ after their last dose. Bur received $4 \mathrm{mg}$ i.m. of betamethasone weekly. The patients' lymphocytes were studied when they were clinically stable and not infected. Two patients in group II were subsequently studied during an acute herpes simplex infection. Patient Pra had bilateral ophthalmic herpes, and patient Gre had cutaneous herpes of both arms, chest, abdomen, and face.

Lymphocyte isolation. Lymphocytes were isolated from 
anticoagulated venous blood by a slight modification of the method described by Perlmann et ai. (8). Briefly, erythrocytes were sedimented in $3 \%$ dextran, the mononuclear cell-rich supernate was incubated with colloidal iron, and the lymphocytes isolated by Ficoll-Hypaque centrifugation. Because $<2 \%$ of these cells ingested latex particles, no attempts were made to remove any remaining phagocytic cells adherent to plastic. For rosette assays, $5 \times 10^{6} / \mathrm{ml}$ lymphocytes were suspended in Tris-buffered Hanks' balanced salt solution, $\mathrm{pH} 7.4$, containing $2.5 \%$ heat-inactivated fetal calf serum (TH). As shown (3), the contamination of such isolated lymphocytes with basophils is very low.

Rosette assays. The reagents and methods for detecting $\mathrm{Fc}_{\boldsymbol{\epsilon}}$ and $\mathrm{Fc}_{\gamma}$ receptors, cells with sIgM and sIgD and T cells by rosette assays were exactly as described (5). Lymphocytes with $\mathrm{Fc}_{\epsilon}$ receptors were usually detected with ox erythrocytes $\left(\mathrm{E}_{0}\right)$ coated with glutaraldehyde coupled rabbit IgG $\mathrm{Fab}^{\prime}$ anti- $E_{0}$ and $F_{c}$ IgE fragments. Fixed $E_{0}\left(E_{0}{ }^{\prime}\right)$ (3) coated with IgE myeloma protein (Sha) were used only for mixed rosettes. To ensure specificity of the IgE rosettes, the rosette assays were also performed by including $2 \mathrm{mg} / \mathrm{ml} \mathrm{IgE} \mathrm{myeloma}$ protein Sha as an inhibitor. The per entage of uninhibitable IgE rosettes, which varied from 0 to $0.7 \%$, was subtracted from the percentage obtained in the absence of inhibitor. Between 300 and 1,000 cells were counted to determine the percentage of rosetting cells. Data were analyzed statistically with a Student's $t$ test. $P$ values above 0.05 were not considered statistically significant.

$B$ - and T-cell depletion. For B-cell depletion 10-30 × $10^{6}$ lymphocytes were incubated with a mixture of $\mathrm{E}_{0}$ coated with $\mathrm{F}\left(\mathrm{ab}^{\prime}\right)_{2}$ anti-IgM, IgD, $\kappa$-, or $\lambda$-chain (5). Neuraminidasetreated $\mathrm{E}$ were used for T-cell depletion (6). The cell mixtures were centrifuged at $800 \mathrm{~g}$ for $5 \mathrm{~min}$ and incubated for $1.5 \mathrm{~h}$ at $4^{\circ} \mathrm{C}$. The cells were then gently resuspended, underlayered with Ficoll-Hypaque and centrifuged for $20 \mathrm{~min}$ at $1,600 \mathrm{rpm}(3)$. The interphase cells were collected, washed three times with TH, and used in rosette assays. The erythrocytes of the rosetting cells in the cell button were lysed with $0.9 \% \mathrm{NH}_{4} \mathrm{Cl}$, and the remaining lymphocytes were washed three times with $\mathrm{TH}$. Mixed rosette assays were performed by employing $\mathrm{E}_{0}{ }^{\prime}-\operatorname{IgE}(3)$ and neuraminidase-treated $\mathrm{E}(6)$.

$\operatorname{IgE}$ determination. Serum $\operatorname{IgE}$ concentrations were determined by double antibody radioimmunoassay as described (9). $1 \mathrm{U}$ of IgE was equivalent to $2.42 \mathrm{ng}$ of $\operatorname{IgE}(10)$.

Monkeys. 10 Macaca monkeys were tested for lymphocyte markers by employing the same reagents used for human cells. Two pigtail monkeys (Macaca nemestrinus) were selected for the experiments because both were 7 -yr-old females weighing $6 \mathrm{~kg}$. One had a high number $(3.3 \%)$ and the other a low number $(0.3 \%)$ of $\mathrm{Fc}_{\epsilon}{ }^{+}$lympocytes. IgE myeloma protein Sha $(20 \mathrm{mg} / \mathrm{ml})$ was ultracentrifuged to remove aggregates (11) and $40 \mathrm{mg}$ was injected i.m. into each of the monkeys on the 1 st $\mathrm{d}$, then $20 \mathrm{mg} / \mathrm{animal}$ per $\mathrm{d}$ on the $2 \mathrm{nd}, 3 \mathrm{rd}$ and, through the 4th $\mathrm{d}$. $10 \mathrm{ml}$ blood was drawn daily from the saphenous vein for lymphocyte isolation.

\section{RESULTS}

Lymphocyte subpopulations in normals. The age, sex, IgE levels, and the $\mathrm{Fc}_{\epsilon}{ }^{+}$lymphocytes of 12 normal donors are shown in Table II. The age and sex distributions of the normal donors were similar to those of the patients. The IgE levels were within normal range. Many donors were examined repeatedly. The differences between individual tests were small and the data, therefore, averaged. The 12 normals had
TABLE II

IgE Concentrations and $\mathrm{Fc}_{\epsilon}{ }^{+}$Lymphocytes of 12 Normal Nonallergic Donors

\begin{tabular}{lllll}
\hline \multicolumn{1}{c}{ Donor } & $\begin{array}{c}\text { Age/ } \\
\text { Sex }\end{array}$ & $\mathrm{IgE}$ & $\mathrm{Fc}_{\epsilon^{+}}$ & $\mathrm{Fc}_{\epsilon^{+}}$ \\
\hline & & $\mu g / m l$ & $\%$ & $m m^{3}$ \\
Bal & $30 \mathrm{M}$ & 0.09 & 0.5 & 15.7 \\
Bla & $38 \mathrm{M}$ & 0.09 & 1.1 & 29.3 \\
Bre & $30 \mathrm{~F}$ & 0.05 & 2.0 & 81.2 \\
Dai & $31 \mathrm{M}$ & 0.20 & 1.0 & 21.7 \\
Fri & $33 \mathrm{M}$ & 0.14 & 1.5 & 50.7 \\
Hei & $21 \mathrm{~F}$ & 0.02 & 1.4 & 34.9 \\
Pat & $33 \mathrm{~F}$ & 0.02 & 0.7 & 20.2 \\
Spi & $45 \mathrm{M}$ & 0.05 & 1.3 & 34.6 \\
Sto & $49 \mathrm{~F}$ & 0.05 & 0.7 & 17.8 \\
Tru & $59 \mathrm{~F}$ & 0.09 & 1.5 & 66.0 \\
Wod & $28 \mathrm{M}$ & 0.05 & 0.7 & 32.2 \\
Yor & $34 \mathrm{~F}$ & 0.09 & 1.9 & 84.4 \\
Average & & 0.08 & 1.2 & 40.7 \\
\pm SD & & 0.05 & 0.5 & 24.3 \\
& & & & \\
\hline
\end{tabular}

$7,470 \pm 1,430$ leukocytes $/ \mathrm{mm}^{3}$ and 3,008 \pm 889 lymphocytes $/ \mathrm{mm}^{3}$ (mean \pm SD). They had $18.7 \pm 7.1 \%$ (572 $\left.\pm 212 / \mathrm{mm}^{3}\right) \mathrm{Fc}_{\gamma}{ }^{+}$cells, $9.7 \pm 2.2 \%\left(318 \pm 129 / \mathrm{mm}^{3}\right) \mathrm{sIgM}^{+}$ cells, $10.4 \pm 5.0 \%\left(341 \pm 202 / \mathrm{mm}^{3}\right) \quad \mathrm{sIgD}^{+}$cells, and $69.6 \pm 10.7 \%\left(2,260 \pm 887 / \mathrm{mm}^{3}\right)$ E-rosetting T cells.

Lymphocyte subpopulations in atopic patients. As described in Methods, patients were divided into three groups based upon severity of disease, serum IgE concentration, and systemic corticosteroid treatment. The 12 patients of group I had more lymphocytes $(3,837 \pm 1,167)$ than the normal individuals. The had only slightly more $\mathrm{Fc}_{\epsilon}{ }^{+}$cells $\left(1.6 \pm 0.9 \%\right.$ or $54 \pm 43 \mathrm{Fc}_{\epsilon}{ }^{+}$ cells $/ \mathrm{mm}^{3}$ ) than the normal subjects (Table I). No obvious correlation between the numbers of $\mathrm{Fc}_{\epsilon}{ }^{+}$cells and the IgE concentration was apparent. The patients of group I had $20.1 \pm 5.9 \%\left(821 \pm 373 / \mathrm{mm}^{3}\right) \mathrm{Fc}_{\gamma}{ }^{+}$cells, $14.2 \pm 6.5 \%\left(552 \pm 336 / \mathrm{mm}^{3}\right) \mathrm{sIgM}^{+}$cells, $15.5 \pm 6.0 \%$ $\left(604 \pm 320 / \mathrm{mm}^{3}\right) \mathrm{sIgD}^{+}$cells, and $68.3 \pm 8.2 \%(2,632$ $\left.\pm 904 / \mathrm{mm}^{3}\right)$ E-rosetting cells. All these values were statistically not significantly different from the cells in the normal group. The $\mathrm{Fc}_{\epsilon}^{+}$and the $\mathrm{B}$ cells were proportionally slightly more increased than the $\mathrm{T}$ cells.

The lymphocyte subpopulations of four patients of group II with severe atopic dermatitis and IgE levels of $29-75 \mu \mathrm{g} / \mathrm{ml}$ are shown in Table III. These patients had statistically significantly $(P<0.001)$ more $\mathrm{Fc}_{\epsilon}{ }^{+}$cells $\left(7.0 \pm 2.0 ; 187 \pm 67 / \mathrm{mm}^{3}\right)$ than the normals and patients of the other groups. They had the lowest number of $\mathrm{FC}_{\gamma}{ }^{+}$cells; this difference was, however, not statistically significant. The percentage and absolute numbers of $\mathrm{B}$ and $\mathrm{T}$ cells were similar to the normals.

Two patients (Gre and Pra) were retested during an acute severe herpes simplex infection. As shown at the bottom of Table III, both patients had lower 
TABLE III

Lymphocyte Subpopulations of Patients with Severe Atopic Disease

\begin{tabular}{|c|c|c|c|c|c|c|c|c|c|c|}
\hline \multirow[b]{2}{*}{ Patient } & \multicolumn{4}{|c|}{ Fc receptors } & \multicolumn{4}{|c|}{ B cells } & \multicolumn{2}{|c|}{ T cells } \\
\hline & $\mathrm{Fc}_{\mathrm{e}}$ & $\mathbf{F c}_{\mathrm{e}}$ & $\mathrm{Fc}_{r}$ & $\mathrm{Fc}_{\gamma}$ & sIgM & sIgM & $\operatorname{sigD}$ & sIgD & E & E \\
\hline & $\%$ & $m m^{3}$ & $\%$ & $m m^{3}$ & $\%$ & $m m^{3}$ & $\%$ & $m m^{3}$ & $\%$ & $m m^{3}$ \\
\hline \multicolumn{11}{|l|}{ Fer } \\
\hline $6 / 29 / 78$ & 4.7 & 117 & 14.3 & 356 & 7.0 & 174 & 5.0 & 125 & 77.0 & 1,917 \\
\hline $8 / 14 / 78$ & 8.3 & 257 & 11.0 & 341 & 8.3 & 257 & 11.7 & 363 & 72.7 & 2,254 \\
\hline Average Fer & 6.5 & 187 & 12.7 & 349 & 7.7 & 216 & 8.4 & 244 & 74.9 & 2,086 \\
\hline \multicolumn{11}{|l|}{ Gre } \\
\hline $6 / 8 / 78$ & 4.6 & 193 & 18.0 & 756 & 15.7 & 659 & 14.7 & 617 & 75.2 & 3,158 \\
\hline $11 / 29 / 78$ & 6.5 & 156 & 10.1 & 242 & 10.7 & 257 & 16.7 & 401 & 76.3 & 1,831 \\
\hline Average Gre & 5.6 & 175 & 14.1 & 499 & 13.2 & 458 & 15.7 & 509 & 75.8 & 2,495 \\
\hline \multicolumn{11}{|l|}{ Kan } \\
\hline $6 / 8 / 78$ & 7.3 & 238 & 24.3 & 792 & 17.4 & 567 & 17.3 & 564 & 69.3 & 2,259 \\
\hline 7/5/78 & 14.0 & 313 & 21.0 & 470 & 16.3 & 365 & 13.7 & 307 & 66.0 & 1,478 \\
\hline $11 / 29 / 78$ & 8.6 & NT & 14.3 & NT & 5.3 & NT & 22.0 & NT & 44.0 & NT \\
\hline Average Kan & 10.0 & 275 & 19.9 & 631 & 13.0 & 466 & 17.7 & 436 & 59.8 & 1,869 \\
\hline \multicolumn{11}{|l|}{ Pra } \\
\hline $6 / 26 / 78$ & 6.4 & 133 & 13.5 & 279 & 10.0 & 207 & 10.0 & 207 & 75.3 & 1,559 \\
\hline 8/7/78 & 5.3 & 71 & 13.7 & 184 & 4.7 & 63 & 5.0 & 67 & 77.7 & 1,041 \\
\hline $12 / 13 / 78$ & 6.0 & 134 & 11.3 & 253 & 4.4 & 99 & 3.0 & 67 & 68.3 & 1,530 \\
\hline Average Pra & 5.9 & 111 & 12.8 & 241 & 6.4 & 121 & 6.0 & 113 & 73.8 & 1,390 \\
\hline Average & 7.0 & 187 & 14.9 & 430 & 10.1 & 315 & 12.0 & 326 & 71.1 & 1,960 \\
\hline$\pm \mathrm{SD}$ & 2.0 & 67 & 3.4 & 171 & 3.5 & 174 & 5.6 & 180 & 7.6 & 460 \\
\hline \multicolumn{11}{|c|}{$\begin{array}{l}\text { Patients Gre and Pra tested at time } \\
\text { of herpes simplex infection }\end{array}$} \\
\hline Gre $7 / 5 / 78$ & 1.3 & 17 & 9.7 & 130 & 6.0 & 80 & 5.7 & 76 & 80.0 & 1,072 \\
\hline Pra $2 / 5 / 79$ & 1.0 & 24 & 15.0 & 354 & 5.6 & 132 & 6.6 & 156 & 69.6 & 1,643 \\
\hline
\end{tabular}

NT, not tested.

numbers of $\mathrm{Fc}_{\epsilon}{ }^{+}$cells than before. Patient Gre had a low lymphocyte count; however, the $\mathrm{Fc}_{\epsilon}{ }^{+}$cells were proportionally much lower than the other lymphocyte subpopulations. Three months later, the $\mathrm{Fc}_{\epsilon}{ }^{+}$lymphocytes returned to preinfection levels in patient Gre.
Patient Pra, despite having more lymphocytes, had $\cong 80 \%$ fewer $\mathrm{Fc}_{\epsilon}{ }^{+}$cells during the herpetic infection.

The lymphocyte subgroups of three patients with severe atopic dermatitis who were receiving corticosteroids systemically (group III) are shown in Table IV.

TABLE IV

Lymphocyte Subpopulations of Patients with Severe Atopic Disorders Receiving Systemic Steroid Treatment

\begin{tabular}{|c|c|c|c|c|c|c|c|c|c|c|}
\hline \multirow[b]{2}{*}{ Patient } & \multicolumn{4}{|c|}{ Fc receptors } & \multicolumn{4}{|c|}{ B cells } & \multicolumn{2}{|c|}{$\mathrm{T}$ cells } \\
\hline & $\mathrm{Fc}_{\varepsilon}$ & $\mathrm{Fc}_{\mathrm{e}}$ & $\mathrm{Fc}_{\gamma}$ & $\mathrm{Fc}_{\gamma}$ & sIgM & sIgM & sIgD & sIgD & $\mathbf{E}$ & $\mathbf{E}$ \\
\hline & $\%$ & $m m^{3}$ & $\%$ & $m m^{3}$ & $\%$ & $m m^{3}$ & $\%$ & $m m^{3}$ & $\%$ & $m m^{3}$ \\
\hline \multicolumn{11}{|l|}{ Bur } \\
\hline 7/7/78 & 0.2 & 5 & 33.3 & 865 & 1.3 & 34 & 1.3 & 71.3 & 71.3 & 1,854 \\
\hline $9 / 5 / 78$ & 0.3 & 14 & 13.3 & 604 & 4.6 & 209 & NT & NT & 83.0 & 3,768 \\
\hline Nic $10 / 19 / 78$ & 0.3 & 17 & 31.0 & 1,705 & 5.0 & 275 & 12.0 & 660.0 & 78.7 & 4,329 \\
\hline Rus $10 / 25 / 78$ & 0.2 & NT & NT & NT & 2.0 & NT & 2.6 & NT & 92.0 & NT \\
\hline
\end{tabular}

NT, not tested. 
They had 10,000-14,500 leukocytes $/ \mathrm{mm}^{3}$ and high lymphocyte counts, observations that had already been made in these patients repeatedly before this study. They had statistically significantly lower percentages of $\mathrm{Fc}_{\epsilon}^{+}$cells than in normals and the lowest percentage of $B$ cells of all groups. The absolute number of B cells was within normal range. In contrast, the absolute numbers of $\mathrm{T}$ cells and $\mathrm{Fc}_{\gamma}$ cells were higher than in the normals. However, these differences were statistically not significant.

Effect of incubation on $\mathrm{Fc}_{\epsilon}{ }^{+}$lymphocytes. Because IgE bound to the lymphocytes in vivo could have inhibited a positive rosette assay, lymphocytes from two normal donors and two atopic patients were incubated for 2, 4, 6, and $18 \mathrm{~h}$ in RPMI-1640 medium containing $2.5 \%$ fetal calf serum, antibiotics and either no or 10,100 , or $500 \mu \mathrm{g} / \mathrm{ml}$ of IgE myeloma protein. The cells were washed with $\mathrm{TH}-2.5 \%$ fetal calf serum and analyzed for $\mathrm{IgE}$ rosettes. The percentage of $\mathrm{Fc}_{\epsilon}{ }^{+}$cells remained unchanged during the first $6 \mathrm{~h}$ of incubation and, as had previously been observed (6), decreased after $18 \mathrm{~h}$ incubation. This result was obtained with lymphocytes of both the normal and atopic donors. Addition of $\mathrm{IgE}$ to the culture medium had no effect on the percentage of IgE-rosetting cells.

$\mathrm{Fc}_{\epsilon}{ }^{+}$cells in sIg-depleted cells. To determine if the $\mathrm{Fc}_{\epsilon}{ }^{+}$lymphocytes in atopic patients were $\mathrm{B}$ cells as in normals $(3,6)$, the lymphocytes of four patients were depleted of anti-Ig-rosetting cells. As shown in Table V, no $\mathrm{Fc}_{\epsilon}{ }^{+}$cells were detected in $\mathrm{sIg}^{+}$cell-depleted lymphocyte preparations of two patients with low numbers of $\mathrm{Fc}_{\epsilon}^{+}$cells (Pra during herpes infection and Rey). In contrast, the $\mathrm{sIg}^{+}$cell-depleted fraction of two patients (Neh, Kan) with 2.6 and $11.7 \mathrm{Fc}_{\epsilon}{ }^{+}$cells in the unfractionated cells still had 0.6 and $0.5 \% \mathrm{Fc}_{\epsilon}{ }^{+}$cells. These depleted cells were then analyzed by a mixed rosette assay with $\mathrm{E}_{0}{ }^{\prime}$-IgE and neuraminidase-treated $\mathrm{E}$. In various experiments, $15-38 \%$ of the $\mathrm{Fc}_{\epsilon}{ }^{+}$cells formed mixed rosettes, indicating that some of the $\mathrm{Fc}_{\epsilon}{ }^{+}$ cells in the sIg-depleted cell population were presumably $\mathrm{T}$ cells. As expected, the sIg-enriched cell population had increased numbers of $\mathrm{Fc}_{\epsilon}{ }^{+}$cells. The cells of patient Kan were also depleted of and enriched for E-rosetting cells. E-depleted cells contained $38.3 \% \mathrm{Fc}_{\epsilon}{ }^{+}$cells, whereas E-enriched cells had only $0.8-1.3 \%$, a lower percentage than the remaining cells with sIg in these preparations. Patient Kan might have had $\mathrm{Fc}_{\epsilon}{ }^{+} \mathrm{T}$ cells that were lost by adhering to the colloidal iron used for isolating the lymphocytes. However, when an E-enriched cell population was prepared from cells that were not treated with colloidal iron, only $0.8 \% \mathrm{Fc}_{\epsilon}^{+}$cells were detected, a value that paralleled the smaller percentage of $B$ cells found in this preparation as compared to the E-enriched cells obtained from iron-treated cells.
TABLE V

Cell Surface Markers of sIg-Depleted Lymphocyte Populations from Atopic Patients

\begin{tabular}{|c|c|c|c|c|c|c|}
\hline \multirow{2}{*}{$\begin{array}{l}\text { Pid- } \\
\text { tient }\end{array}$} & \multirow[b]{2}{*}{ Lymphocytes } & \multicolumn{5}{|c|}{ Rosetting cells } \\
\hline & & $\mathrm{Fc}_{\mathrm{e}}$ & $\mathrm{Fc}_{\gamma}$ & $\mathrm{s}|g|)$ & sIg.M & $\mathrm{E}$ \\
\hline & & & & $\%$ & & \\
\hline \multirow[t]{2}{*}{ Pra } & Unfractionated & 1.0 & 15.0 & 6.6 & NT & 69.6 \\
\hline & sIg depleted & 0.0 & 13.7 & 0.2 & NT & 66.5 \\
\hline \multirow[t]{2}{*}{ Rey } & Unfractionated & 0.4 & 11.7 & 12.2 & NT & 87.8 \\
\hline & sIg depleted & 0.0 & 11.0 & 0.2 & NT & 89.7 \\
\hline \multirow[t]{2}{*}{ Neh } & Unfractionated & 2.6 & 21.4 & 28.8 & NT & 67.0 \\
\hline & sIg depleted & 0.6 & 18.4 & 0.4 & NT & 82.7 \\
\hline \multirow[t]{6}{*}{ Kan } & Unfractionated & 11.7 & 11.0 & 17.0 & 18.0 & 75.0 \\
\hline & sIg depleted & 0.5 & 7.7 & 0.0 & 1.7 & 89.5 \\
\hline & E depleted & 38.3 & 39.3 & 70.0 & 64.5 & 8.0 \\
\hline & sIg enriched & 23.0 & 23.7 & NT & 57.3 & 33.7 \\
\hline & E enriched & 1.3 & 7.3 & 8.0 & 8.7 & 82.0 \\
\hline & E enriched* & 0.8 & 8.0 & 4.7 & 3.7 & 76.7 \\
\hline
\end{tabular}

* E-enriched cells from mononuclear cells isolated by Ficoll-Hypaque centrifugation without prior incubation with colloidal iron.

$F c_{\epsilon}^{+}$lymphocytes in monkeys injected with IgE. 10 Macaca monkeys ( 7 Rhesus, 2 pigtail, and 1 stump tail) were analyzed for lymphocyte subpopulations. The mean and SD of the cells with different lymphocyte markers were not significantly different from those of normal humans: $\mathrm{Fc}_{\epsilon^{+}}^{+}, 1.0 \pm 0.9 \% ; \mathrm{Fc}_{\gamma}^{+}, 20.8 \pm 8.1 \%$; $\operatorname{sIgM}^{+}, 9.8 \pm 5.8 \% ; \operatorname{sIgD}^{+}, 9.2 \pm 3.2 \% ; \mathrm{E}^{+}, 63.0 \pm 7.7 \%$. Two sex- and age-matched pigtail monkeys with extreme high and low $(3.3 \%$ and $0.3 \%)$ numbers of $\mathrm{Fc}_{\epsilon}{ }^{+}$cells were injected on 4 consecutive $d$ with IgE myeloma protein Sha. The IgE levels rose from $0.29 \mu \mathrm{g} / \mathrm{ml}$ up to $125 \mu \mathrm{g} / \mathrm{ml}$ for $5 \mathrm{~d}$ and dropped thereafter to the preimmune levels. Daily lymphocyte testing showed percentages of $\mathrm{Fc}_{\epsilon}^{+}$cells similar to the preinjection values except on $1 \mathrm{~d}$ in one monkey, whose $\mathrm{Fc}_{\epsilon}{ }^{+}$cells rose to $7 \%$ on the 6 th $\mathrm{d}$ after the first IgE injection. Except for this value, the $\mathrm{Fc}_{\epsilon}{ }^{+}$lymphocytes varied from 1.0 to $3.6 \%$ (average, $2.6 \%$ ) and $0.0-1.4 \%$ (average, $0.6 \%$ ), respectively, in the two monkeys during the 14-d observation period.

\section{DISCUSSION}

These studies demonstrate that patients with atopic disorders and severe hyperimmunoglobulinemia $\mathrm{E}$ have significantly more $\mathrm{Fc}_{\mathrm{\epsilon}}^{+}$lymphocytes than normal individuals. However, similarly afflicted patients treated systemically with corticosteroids generally have lower percentages and absolute numbers of $\mathrm{Fc}_{\epsilon}{ }^{+}$ 
cells than normals. Atopic patients with relatively mild disease and normal or moderately elevated IgE levels had a slightly increased number of $\mathrm{Fc}_{\epsilon}{ }^{+}$cells that was no statistically significant from the normals. Nevertheless, this difference may acquire greater significance in the analysis of a larger number of patients. Antigen specific IgE levels rise and fall with seasonal antigen exposure (12). The $\mathrm{Fc}_{\epsilon}{ }^{+}$cells could, conceivably, increase in the circulation during a specific phase of exposure to a sensitizing agent and resultant $\operatorname{IgE}$ response, whereas these cells are found in lower numbers at other times. This phenomenon would explain why an increase of $\mathrm{Fc}_{\epsilon}{ }^{+}$cells is detectable only in the patients with severe and chronic disease. Serial analyses of patients during symptomatic and asymptomatic phases of atopic disease are necessary to test this assumption. Recently, Yodoi et al. (13) reported that $\mathrm{Fc}_{\boldsymbol{\epsilon}}{ }^{+}$lymphocytes increased in lymph nodes of rats after infection with Nippostrongylus brasiliensis. This experimentally induced increase resembles the rise in $\mathrm{Fc}_{\epsilon}{ }^{+}$cells of severely atopic patients and both situations suggest that the $\mathrm{F}_{\epsilon}{ }^{+}$cells play an important role in the formation, regulation, and(or) metabolism of IgE antibodies.

We have previously reported that the $\mathrm{Fc}_{\epsilon}{ }^{+}$lymphocytes in normals are $\mathbf{B}$ cells $(3,5,6)$. Our current analysis of sIg-depleted cells indicate that this is also true in patients with atopic illness. However, in two patients with increased numbers of $\mathrm{Fc}_{\epsilon}{ }^{+}$lymphocytes, $\mathrm{Fc}_{\epsilon}{ }^{+}$cells were found in sIg-depleted cell fractions that formed mixed $\mathrm{Fc}_{\epsilon}-\mathrm{E}$ rosettes and were presumably $\mathrm{T}$ cells. Because of the small number of such $\mathrm{T}$ cells, the $F_{c_{\epsilon}}$ rosette formation could have been nonspecific. This did, however, appear unlikely, since monomeric $\mathrm{IgE}$ at $2 \mathrm{mg} / \mathrm{ml}$ completely inhibited the IgE rosettes in these preparations. Yodoi et al. (13) also found $\mathrm{Fc}_{\epsilon}{ }^{+}$ $\mathrm{T}$ cells in E-enriched cell populations of atopic patients and in rats infected with $N$. brasiliensis. However, as shown in four of our patients, the number of $\mathrm{Fc}_{\boldsymbol{\epsilon}}{ }^{+} \mathrm{T}$ lymphocytes is small and we could not exclude that these cells were E-rosetting B cells $(14,15)$. Fc receptors for IgG (16), IgM (17), and recently IgA $(18,19)$ have been found in both $\mathrm{T}$ - and B-cell populations. It is likely, therefore, that all individuals have subsets of $\mathrm{Fc}_{\epsilon}{ }^{+} \mathrm{B}$ and T cells; however, because of the small number of $\mathrm{Fc}_{\epsilon}^{+}$cells in most donors, the $T$ cells are not as easily demonstrable.

The lymphocyte preparations were treated with colloidal iron because $\cong 25 \%$ of normal human monocytes form rosettes with Fc-IgE-coated indicator cells (20). These rosettes can only be inhibited with $10 \mathrm{mg} / \mathrm{ml}$ of $\mathrm{IgE}$, whereas the rosettes formed by lymphocytes are completely inhibited by $1-2 \mathrm{mg} / \mathrm{ml}$. The small percentage of uninhibitable rosettes in the present experiments were therefore most likely monocytes. If lymphocytes were isolated by Ficoll-Hypaque centrifugation omitting the iron treatment, the number of rosetting monocytes made it impossible to accurately determine the percent of $\mathrm{Fc}_{\boldsymbol{\epsilon}}$-rosetting lymphocytes.

No significant differences in the percentages and absolute numbers of $\mathrm{B}, \mathrm{T}$, and $\mathrm{Fc}_{\gamma}{ }^{+}$lymphocytes were found between the three groups of patients and normal humans. Interestingly, the patients with severe atopic disease and highly elevated $\mathrm{Fc}_{\epsilon}{ }^{+}$cell numbers (group II) had the lowest number of $\mathrm{Fc}_{\gamma}{ }^{+}$cells. We have previously shown that normal lymphocytes with $\mathrm{Fc}_{\epsilon}$ receptors do not have $\mathrm{Fc}_{\gamma}$ receptors (3). It is conceivable, therefore, that these patients had decreased levels of $\mathrm{Fc}_{\gamma}{ }^{+} \mathrm{B}$ cells concomitant with increased $\mathrm{Fc}_{\epsilon}{ }^{+} \mathrm{B}$ cells.

Three patients with severe atopic dermatitis treated systemically with corticosteroid had lower numbers of $\mathrm{Fc}_{\epsilon}{ }^{+}$lymphocytes than normals. They also had the lowest percentage of B cells; however, because they had elevated lymphocyte counts, the absolute number of B cells was within normal range. Corticosteroids may have suppressed these cells and(or) their ability to form the $\mathrm{Fc}_{\epsilon}$ receptors or caused a redistribution of the cells from the blood to lymphoid organs.

Notably, when two of the patients of group II developed a severe herpes simplex infection, the number of $\mathrm{Fc}_{\epsilon}{ }^{+}$cells decreased markedly. The mechanism for this is not understood. It could be the effect of endogenous corticosteroids or other active substances formed in response to the viral infection such as virally induced interferon.

The number of $\mathrm{Fc}_{\mathrm{\epsilon}}$ receptors on lymphocytes could be modulated by the serum IgE concentrations as has been suggested for basophils (21). At a high IgE concentration, the cells could form more $\mathrm{Fc}_{\epsilon}$ receptors and are then detectable between $\mathrm{Fc}_{\epsilon}{ }^{+}$cell number and serum IgE level in patients with moderately increased IgE levels, all patients with very high IgE levels (group II) had high numbers of $\mathrm{Fc}_{\epsilon}{ }^{+}$cells. To test if a very high $\mathrm{IgE}$ concentration induces $\mathrm{Fc}_{\epsilon}$-rosetting cells, two Macaca monkeys were injected with a human IgE myeloma protein. This did not, however, result in an increase of $\mathrm{Fc}_{\epsilon}^{+}$cells. Although human IgE was expected to affect monkey lymphocytes similarly to homologous IgE, because human and monkey IgE cross-react extensively (22), the lack of an increase in $\mathrm{Fe}_{\epsilon}$-rosetting cells in these monkeys does not rule out a possible effect of serum IgE on the expression of $F_{\epsilon}$ receptors on human cells. The affinity of the heterologous IgE to the monkeys' cell receptors could have been too low to increase the $\mathrm{Fc}_{\epsilon}$ receptor synthesis. Yodoi et al. (13) reported that rat lymphocytes cultured with $\mathrm{IgE}$, but not IgG-induced $\mathrm{Fc}_{\epsilon}{ }^{+}$ lymphocytes. In contrast, incubation with $\operatorname{IgE}$ of lymphocytes from either normal or atopic humans did not result in an increase of $\mathrm{Fc}_{\epsilon}$ receptor-positive 
lymphocytes. Whether this is reflecting a species or methodological difference remains to be investigated.

\section{ACKNOWLEDGMENTS}

The authors thank Dr. R. McIntire and K. Ishizaka for plasma of IgE myeloma patient Sha, and Dr. R. N. Hamburger for helpful suggestions. We thank Ms. Gloria Portillo, Lisa Heinz, and Dolores Melvin for excellent technical, Mrs. Andrea Rothman and Mrs. Phyllis Minick for editorial, and Mrs. Margaret Stone for secretarial assistance.

This study was supported by U. S. Public Health Service grant AI-10734 and Biomedical Research Support program grant RRO-5514.

\section{REFERENCES}

1. Ishizaka, K. 1970. Human reaginic antibodies. Annu. Rev. Med. 21: 187-200.

2. Lawrence, D. A., W. O. Weigle, and H. L. Spiegelberg. 1975. Immunoglobulins cytophilic for human lymphocytes, monocytes, and neutrophils. J. Clin. Invest. 55: $368-376$.

3. Gonzalez-Molina, A., and H. L. Spiegelberg. 1977. A subpopulation of normal human peripheral B lymphocytes that bind IgE. J. Clin. Invest. 59: 616-624.

4. Gonzalez-Molina, A., and H. L. Spiegelberg. 1976. Binding of IgE myeloma proteins to human cultured lymphoblastoid cells. J. Immunol. 117: 1838-1845.

5. Spiegelberg, H. L., and P. M. Dainer. 1979. Fc receptors for IgG, IgM and IgE on human leukemic lymphocytes. Clin. Exp. Immunol. 35: 286-295.

6. Hellström, U., and H. L. Spiegelberg. 1979. Characterization of human lymphocytes bearing Fc receptors for IgE from blood and lymphoid organs. Scand. J. Immunol. 9: 75-86.

7. Meinke, G. C., A. M. Magro, D. A. Lawrence, and H. L. Spiegelberg. 1978. Characterization of an IgE receptor isolated from cultured B-type lymphoblastoid cells. J. Immunol. 121: 1321-1328.

8. Perlmann, H., P. Perlmann, G. R. Pape, and G. Hallden. 1976. Purification, fractionation and assay of antibodydependent lymphocyte effector cells ( $\mathrm{K}$ cells) in human blood. Scand. J. Immunol. 5(Suppl.): 57-68.

9. Gleich, G. J., A. K. Averbeck, and H. A. Swedlund. 1971.
Measurement of IgE in normal and allergic serum by radioimmunoassay. J. Lab. Clin. Med. 77: 690-698.

10. Bazaral, M., and R. N. Hamburger. 1972. Standardization and stability of immunoglobulin E (IgE). J. Allergy. 49: 189-191.

11. Spiegelberg, H. L., and W. O. Weigle. 1968. The production of antisera to human ${ }_{\gamma} G$ subclasses in rabbits using immunological unresponsiveness. J. Immunol. 101: $377-380$.

12. Berg, T., and S. G. O. Johansson. 1969. IgE concentrations in children with atopic diseases. A clinical study. Int. Arch. Allergy Appl. Immunol. 30: 219-232.

13. Yodoi, J., T. Ishizaka, and K. Ishizaka. 1979. Presence of T cells bearing IgE receptors. Fed. Proc. 38: 1088. (Abstr.)

14. Bentwich, Z., S. D. Douglas, F. P. Siegal, and H. G. Kunkel. 1973. Human lymphocyte-sheep erythrocyte rosette formation: some characteristics of the interaction. Clin. Immunol. Immunopathol. 1: 511-522.

15. Dickler, H. B., N. F. Adkinson, Jr., and W. D. Terry. 1974. Evidence for individual human peripheral blood lymphocytes bearing both B and T cell markers. Nature (Lond.). 247: 213-215.

16. Dickler, H. B. 1976. Lymphocyte receptors for immunoglobulin. Adv. Immunol. 24: 167-214.

17. Moretta, L., S. R. Webb, C. E. Grossi, P. M. Lydyard, and M. D. Cooper. 1977. Functional analysis of two human subpopulations: help and suppression of $B$ cell responses by $T$ cells bearing receptors for $\operatorname{IgM}\left(T_{M}\right)$ or $\operatorname{IgG}\left(T_{G}\right)$. J. Exp. Med. 146: 184-200.

18. Strober, W., N. E. Hague, L. G. Lum, and P. A. Henkart. 1978. IgA-Fc receptors on mouse lymphoid cells. J. Immunol. 121: 2440-2445.

19. Lum, L. B., A. V. Muchmore, D. Kerren, J. Decker, I. Koski, W. Strobert, and R. M. Blaese. 1979. A receptor for human IgA on human T lymphocytes. J. Immunol. 22: 65-69.

20. Melewicz, F. M., and H. L. Spiegelberg. 1979. IgE mediated cytotoxicity by human monocytes. Fed. Proc. 38: 925. (Abstr.)

21. Malveaux, F. J., M. C. Conroy, N. F. Adkinson, and L. M. Lichtenstein. 1978. IgE receptors on human basophils. Relationship to serum IgE concentration. J. Clin. Invest. 62: 176-181.

22. Ishizaka, K., T. Ishizaka, and T. Tada. 1969. Immunoglobulin $\mathrm{E}$ in the monkey. J. Immunol. 103: 445-453. 